Heile et al.

\title{
Bilateral Asymmetry of the Forearm Bones as Possible Evidence of Antemortem Trauma in the StW 573 Australopithecus Skeleton from Sterkfontein Member 2 (South Africa)
}

\author{
A.J. Heile 1 \\ Travis Rayne Pickering $1,2,3 *$ \\ Jason L. Heaton ${ }^{2,3,4}$ \\ R.J. Clarke²
}

1. Department of Anthropology, University of Wisconsin-Madison, Madison, Wisconsin, 53706, USA

2. Evolutionary Studies Institute, University of the Witwatersand, WITS 2050, Johannesburg, South Africa

3. Plio-Pleistocene Palaeontology Section, Department of Vertebrates, Ditsong National Museum of Natural History (Transvaal Museum), Pretoria, South Africa

4. Department of Biology, Birmingham-Southern College, Birmingham, Alabama, 35245, USA

To Whom Correspondence Should be Addressed: T.R. Pickering, Department of Anthropology, University of Wisconsin-Madison, 1180 Observatory Drive, Madison, Wisconsin, 53706; Phone: (608) 262-5818; E-mail: tpickering@wisc.edu 


\title{
Heile et al.
}

\begin{abstract}
The 3.67-million-year-old StW 573 Australopithecus skeleton is important for the light it sheds on the paleobiology of South African species of that genus, including, as discussed here, how the possible pathology of the specimen informs our understanding of Australopithecus behavior. The StW 573 antebrachium exhibits bilateral asymmetry, with significantly more longitudinally curved left forearm bones than right. Arguing from a comparative perspective, we hypothesize that these curvatures resulted from a fall onto a hyperextended, outstretched hand. It is unlikely that the fall was from a significant height and might have occurred when the StW 573 individual was a juvenile. This type of plastic deformation of the forearm bones is well-documented in modern human clinical studies, especially among children between the ages of four and ten years who tumble from bicycles or suffer other common, relatively low-impact accidents. Left untreated, such injuries impinge normal supination and pronation of the hand, a condition that could have had significant behavioral impact on the StW 573 individual.
\end{abstract}

Keywords: Australopithecus; Paleopathology; Bone curvature; Traumatic bowing fracture 


\section{Heile et al.}

\section{Introduction}

The 3.67-million-year-old StW 573 ("Little Foot") Australopithecus skeleton, from Member 2 of the Sterkfontein Formation (South Africa), was discovered by R.J. Clarke in a sequence of steps that unfolded in the laboratory and field over the years of 1995 through 1997 (see, e.g., Dugard, 1995; Clarke, 2018). In a series of papers, Clarke and his colleagues (Clarke and Tobias, 1995; Clarke, 1998, 1999, 2002, 2007, 2008, 2018; Pickering et al., 2004; Granger et al., 2015; Stratford et al., 2017; Beaudet et al., 2018a,b; Clarke, 2018; Clarke et al., 2018; Crompton et al., 2018; Heaton et al., 2018) have provided information on the skeleton's stratigraphic and taphonomic circumstances, geochronological position, taxonomic status, and functional morphology.

The last set of analyses conclude that the "Little Foot" individual (from here, LF), when alive, was an orthograde terrestrial biped and also possessed significant adaptations for climbing (e.g., Clarke and Tobias, 1995; Beaudet et al., 2018b; Carlson et al., 2018; Crompton et al., 2018; Heaton et al., 2018). It is in this context that the observed asymmetry of the LF skeleton's right (lacking significant diaphyseal curvature) and left (displaying significant diaphyseal curvature) forearm bones (Heaton et al., 2018) is of particular interest (Fig 1). ${ }^{1}$

Like other diaphyseal bone curvatures in primates (e.g., Susman, 1979; Bruns et al., 2002; Richmond, 2007), those of the radius (lateral) and ulna (dorsal) are probably the result of both genetics and limb function. As to the latter, biomechanical studies suggest that radial lateral bending is, in part, a plastic response to the exertion of the pronator teres during pronation (Galtés et al., 2009), while it is widely hypothesized that ulnar dorsal curvature results from the powerful engagement of both pronator and supinator muscles and as an adaptation that expands the

${ }^{1}$ The differential maximum lengths of the $\mathrm{LF}$ radii (left $=236 \mathrm{~mm}$; right estimate $=250 \mathrm{~mm}$; Heaton et al., 2018) also reflects this variance in curvature. 


\section{Heile et al.}

interosseous membrane for insertion of enlarged digital flexors (e.g., Miller, 1933; Knussmann, 1967; Swartz, 1990). In this hypothetical context, it is notable that below-branch suspensory locomotorists show significantly curved radii and ulnae (e.g., Knussmann, 1967).

Based on muscle weight, bone weight, and osteometrics, forelimb bone asymmetries have been documented in several extant primates (e.g., Schultz, 1937; Dhall and Singh, 1977; Falk et al., 1988; McGrew and Marchant, 1997). Further, in a study of the total subperiosteal areas of wild-caught chimpanzee (Pan troglodytes) humerus diaphyses, Hunt's (1991) observations on that animal's positional behavior was cited to suggest that bilateral asymmetry of this element might be due to unimanual suspension (Sarringhaus et al., 2005). Thus, it is not unreasonable to predict a similar bilateral asymmetry of forelimb bone curvatures in hominoids that regularly engage in belowbranch positions and activities. To our knowledge, no published data are available to test this prediction. However, anecdotally, we have not observed significant bilateral curvature asymmetries in the antebrachial segments of chimpanzee and bonobo (Pan paniscus) skeletons that we have studied.

It seems as likely, if not more, that the differential morphology of the right and left forearm bones of the LF skeleton are due to injury than to normal in vivo functional demands of its forelimbs. Specifically, we hypothesize that, as a juvenile, the LF individual suffered acute plastic bowing deformation of its left forearm. We base this hypothesis on the greater likelihood that it is the curved, left, and not the straight right, antebrachial elements of the LF individual that are abnormal. We argue this point from both observational and comparative perspectives. First, there is no apparent antemortem trauma to the right humerus, radius, or ulna of LF (Heaton et al., 2018). In addition, the bones display no sign of atrophy, which is predicted if the right upper limb was in disuse during the life of LF. Second, survey of the literature on forearm bone curvature in non- 


\section{Heile et al.}

Homo late Pliocene and early Pleistocene hominins predicts that a small-bodied Australopithecus, such as LF, should possess relatively straight radii and ulnae.

If our hypothesis is correct, then the curved left antebrachial elements of the LF skeleton stand as some of the earliest evidence of traumatic antemortem skeletal injury in the hominin ${ }^{2}$ fossil record. Plastic deformation of the arm requires longitudinal forces within a limited range of magnitude. These forces exceed those causing temporary elastic deformation and approach fracture-inducing forces; the resulting bowing remains unless physically corrected (Borden 1974, 1975). It is hypothesized here that the dorsal diaphyseal curvature evidenced in LF's left forearm represents traumatic bowing from a fall onto a hyperextended, outstretched hand. This likely occurred when LF was young, as mature bone is more prone to fracture catastrophically, rather than bow (Borden 1975).

\section{Materials and Methods}

The goal of the first part of our analysis of the antebrachial asymmetry of LF is to place its radial and ulnar curvatures in comparative fossil context. A widely used method for representing forearm bone curvature in paleoanthropology is the calculation of curvature subtenses (e.g., Aiello et al. 1999) (Fig. 2). No matter the measurement(s) of curvatures, though, as discussed above, it seems that they can be induced by a number of different processes or combination of processes. Among those causes is allometry, as it is generally appreciated that the more robust an ulna is anteroposteriorly, the greater its curvature will be (e.g., Drapeau et al., 2005).

\footnotetext{
2 Based on White (2002), Clarke (2012), and White et al. (2015), RJC objects to the use of the term "hominin," and prefers the use of the term "hominid."
} 


\section{Heile et al.}

With this understanding, we consulted the literature to obtain length, anteroposterior midshaft diameter, and curvature subtense values (terms defined in Table 1) for relevant late Pliocene and early Pleistocene non-Homo hominin ulnae (Drapeau et al., 2005; Churchill et al., 2013) in order to compare those values to those of the left ulna of LF (Heaton et al., 2018). Relevant exceptions to this were the anteroposterior midshaft diameter and curvature subtense of the Australopithecus sediba MH2 ulna, which we calculated from published photographs (Rein et al., 2017) using image analysis software. We omitted radius measurements from our study because of the paucity of complete and near-complete Australopithecus and Paranthropus comparative radii. Next, in order to contextualize these fossil results, we reviewed the clinical literature on traumatic forearm bone bowing of modern humans.

\section{Results and Discussion}

The left ulna of LF displays a comparatively high estimated curvature value of 12, much higher than those of other measurable Australopithecus ulnae and nearer to the curvature values of the early Pleistocene hominin ulnae OH 36 (Olduvai Gorge, Tanzania) and L40-19 (Omo, Ethiopia) (Table 2). Like OH 36 and L40-19, the left ulna of LF is relatively large. The large size of these elements may account, at least in part, for their significant curvatures (e.g., Knussmann, 1967; Drapeau et al., 2005). In this context, it is not irrelevant to note that the diaphysis of the largest known radius in the early hominin fossil record, $\mathrm{OH} 80$, from Olduvai, is also apparently strongly curved (Domínguez-Rodrigo et al., 2013).

However, it is also possible that the extreme curvatures of $\mathrm{OH} 36, \mathrm{~L} 40-19$, and $\mathrm{OH} 80$ are taxonomic-specific, caused by genetics and/or locomotor adaptations (such as forelimb-dominated climbing). All of these specimens have been assigned (at least tentatively) to the genus Paranthropus (e.g., Howell and Wood, 1987; Aiello et al., 1999; Domínguez-Rodrigo et al., 2013). If 


\section{Heile et al.}

that is the case, then the curved ulna of LF is particularly intriguing given that it derives from an Australopithecus individual, ${ }^{3}$ and that even large Australopithecus ulnae, such as AL 438-1, are only moderately curved (Table 2). And, although there are fewer complete or near-complete Australopithecus radii than ulnae, they, too, seem to show rather straight diaphyses, more comparable to diaphyseal profiles of modern human forearm bones (e.g., Johanson et al., 1982; Heinrich et al., 1993; Toussaint et al., 2003; Pickering et al., 2018).

In sum, the curvature of the left antebrachium of LF is unexpected in a comparative fossil context and seems to suggest that it is this side that is abnormal and not the straight, right forearm bones of the skeleton. As discussed in the introduction, we have been unable to find data on modern primates to suggest that asymmetrical bowing of the forearm bones results from unimanual locomotor, positional, or other behaviors. Thus, it is most parsimonious to hypothesize that the curvature of the left forearm bones of LF resulted from an antemortem trauma.

There is a large body of experimental work on plastic deformation of mammalian long limb bone diaphyses (e.g., Chamay 1970; Chamay and Tschantz 1972; Lanyon, 1980; Lieberman et al. 2003). Traumatic bowing fracture (TBF) is a specific type of plastic deformation that, in modern human clinical circumstances, most often affects the bones of the antebrachium. It presents as a distinct abnormal curvature of the limb bone diaphysis, with microfracturing on the concave side of the bow (e.g., Borden 1974, 1975). Though rare, adult cases of TBF of the forearm bones have been documented and usually result from slow bending forces such as those caused by entrapment in

\footnotetext{
${ }^{3}$ Taxonomic determination of LF is based primarily on its craniodental anatomy (Clarke et al., 2018). However, we also note that that the left ulna of the specimen also shows typical Australopithecus features (Heaton et al., 2018), such as an anteriorly directed and minimally keeled trochlear notch (Aiello et al., 1999; Drapeau 2004, 2008).
} 


\section{Heile et al.}

rotating machines (e.g., Greene 1982; Simonian and Hanel 1996; Sclamberg et al. 1998; Sen et al., 2004; Lefaivre et al. 2007; Tada et al., 2008; Tianhao et al., 2014). However, most often, it is children between the ages of four and ten years that experience TBF (Vorlat and De Boeck 2003) as a result of falls onto outstretched, hyperextended hands (e.g., Borden 1974, 1975; Naga and Broadrick 1977; Crowe and Swischuk 1977; Aponte and Ghiatas 1989; Vorlat and De Boeck 2003; Musters and Colaris 2017). Descriptions of TBF in children vary in their level of detail, but it appears as though most falls that result in bowing are from rather insignificant heights and are, at least sometimes, associated with varying degrees of momentum. For instance, bicycle accidents are a commonly reported cause of injury (e.g., Borden 1974, 1975; Naga and Broadrick 1977; Crowe and Swischuk 1977; Komara et al. 1986).

\section{Conclusion}

The fossil record of late Pliocene and early Pleistocene African hominins includes several excellently preserved partial skeletons, including the Australopithecus specimens A.L. 288-1 ("Lucy," Hadar, Ethioipia), KSD-VP-1 ("Kadanuumuu," Woranso-Mille, Ethiopia), DIK-1-1 ("Selam," Dikika, Ethiopia), Sts 14 and StW 431 (Sterkfontein), and MH1 and MH2 (Malapa, South Africa), as well as the H. ergaster "Nariokotome Boy" (KNM-WT 15000) from West Turkana, Kenya. Research on these, and on other less complete specimens, has revealed various lines of evidence related to the peri- and postmortem fate of our early ancestors. Those data support hypotheses that early hominins, like modern humans, suffered various kinds of fatal misfortune, including succumbing to the predation of carnivores (e.g., Brain, 1981, Pickering et al., 2004), raptors (Berger and Clarke 1995), and possibly crocodilians (Njau and Blumenschine, 2012; contra, Baquedano et al., 2012), to falls from significant heights (L'Abbé et al., 2015; Kappelman et al., 2012), and to septicemia (Walker, 1993). 


\section{Heile et al.}

And, although there have been several interesting observations of early hominin dental and periodontal defects (e.g., Robinson, 1956; White, 1978; Tobias, 1991; Walker, 1993; Ripamonti et al., 1997; Guatelli-Steinberg, 2003), abnormal bone apposition (Walker et al., 1982; Rothschild et al., 1995), and bony pathologies (Cook et al., 1983; Latimer and Ohman, 2001; D'Anastasio et al., 2009; Domínguez-Rodrigo et al., 2012), less is known about traumatic antemortem damage to skeletons of this great antiquity. It has been proposed that the $\sim 3.6$ Ma Kadanuumuu skeleton shows evidence of an unhealed fibular fracture, incurred when the individual was a juvenile (Lovejoy et al., 2016), and the $~ 3.0$ Ma Australopithecus afarensis A.L. 333-107 humerus, from Hadar might preserve a healed proximal fracture (Lovejoy et al., 1982). With the likely acute plastic bowing deformation of its left antebrachium, the LF skeleton joins the last group as a possible example of skeletal trauma incurred during the life of an important early hominin specimen.

If indeed the curvature exhibited in LF's left antebrachium represents a TBF, this has possible implications for the ways in which the individual interacted with the environment. First, if modern humans serve as a reasonable referent in this case, then it is more likely than not that LF's injury occurred prior to adulthood. As discussed above, most descriptions of the causes of childhood TBF are vague, but, based on that literature, it seems most reasonable to suggest that the injury was incurred under low-impact conditions. In this sense, the severity of the suggested LF injury is unlike the trauma proposed to have been incurred by Lucy. Kappelman et al. (2016) report on possible greenstick fractures of multiple skeletal elements of Lucy and suggest these injuries resulted from a fall of great heights. They propose these fractures likely caused damage to Lucy's internal organs, resulting in her death, and hypothesize the fall was from a tree, thus offering evidence for arborealism in A. afarensis. Although some of the LF morphology is reflective of arboreal locomotor behavior (Clarke and Tobias 1995; Beaudet et al., 2018b; Crompton et al., 2018), the proposed LF injury cannot be used in support of arborealism, as TBF can occur at ground level. 


\section{Heile et al.}

In the case of modern humans, TBFs can result in the loss of full pronation and supination unless corrected (e.g., Borden 1974, 1975; Greene 1982; Sanders and Heckman 1984; Anderson et al., 1994). It seems safe to assume that LF did not receive corrective treatment for TBF. That said, permanent unimanual limitation of forearm rotation may have hindered her climbing and manipulatory abilities, which is significant for an organism that otherwise appears to have been reasonably adapted to climbing (Clarke and Tobias 1995; Beaudet et al., 2018b; Crompton et al., 2018) and that possessed a hand that shows at least some modern humanlike characteristics (Clarke 1999). That the LF individual lived to an advanced age (Clarke et al., 2018) with such a possible handicap raises obvious questions about sociality and intraspecific care in South African Australopithecus. 


\section{Heile et al.}

\section{Acknowledgements}

This work was funded by a Kellet Mid-Career Award from the University of Wisconsin-Madison (USA) awarded to TRP and by additional funds from the National Research Foundation (South Africa) awarded separately to Dominic Stratford and Kathleen Kuman. Thanks to Abel Molepolle and Andrew Phaswana for their continued assistance and camaraderie, as well as the rest of the Little Foot research team, Amelie Beaudet, Laurent Bruxelles, Kristian Carlson, Robin Crompton, Tea Jashashvili, Kathleen Kuman, Juliet McClymont, and Dominic Stratford. 


\section{Heile et al.}

\section{References}

Aiello, L.C., Wood, B., Key, C., Lewis, M., 1999. Morphological and taxonomic affinities of the Olduvai ulna (OH 36). American Journal of Physical Anthropology 109, 89-110.

Anderson, I.F., 1994. Plastic bowing of the forearm on more mature skeleton. ANZ Journal of Surgery $64,132-13$

Aponte, J.E., Ghiatas, A., 1989. Acute plastic bowing deformity: A review of the literature. The Journal of Emergency Medicine 7, 181-184.

Baquedano, E., Domínguez-Rodrigo, M., Musiba, C., 2012 An experimental study of large mammal bone modification by crocodiles and its bearing on the interpretation of crocodile predation at FLK Zinj and FLK NN3. Journal of Archaeological Science 39, 1728-1737.

Beaudet, A., Clarke, R., de Jager, E., Bruxelles, L., Carlson, K., Crompton, R., de Beer, F., Dhaene, J., Heaton, J., Jakata, K., Jashashvili, T., Kuman, K., McClymont, J., Pickering, T.R., Stratford, D. 2018a.The endocast of StW 573 and hominin brain evolution. Journal of Human Evolution, in submission.

Beaudet, A., Clarke, R., de Jager, E., Bruxelles, L., Carlson, K., Crompton, R., de Beer, F., Dhaene, J., Heaton, J., Jakata, K., Jashashvili, T., Kuman, K., McClymont, J., Pickering, T.R., Stratford, D. 2018b. The bony labyrinth of StW 573: taxonomic, evolutionary and functional implications. Journal of Human Evolution, in submission.

Berger, L. R., Clarke, R. J., 1995. Eagle involvement in accumulation of the Taung Child fauna. Journal of Human Evolution 29, 275-99. 


\section{Heile et al.}

Borden, S., 1974. Traumatic bowing of the forearm in children. The Journal of Bone \& Joint

Surgery 56, 611-616.

Borden, S., 1975. Roentgen recognition of acute plastic bowing of the forearm in children.

American Journal of Roentgenology 125, 524-530.

Brain, C.K., 1981. The Hunters or the Hunted? An Introduction to African Cave Taphonomy. Chicago:

University of Chicago Press.

Bruns, W., Bruce, M., Prescott, G., Maffulli, N., 2002. Temporal trends in femoral curvature and

length in medieval and modern Scotland. American Journal of Physical Anthropology 119,

$224-230$.

Chamay, A. 1970. Mechanical and morphological aspects of experimental overload and fatigue in bone. Journal of Biomechanics 3, 263-270.

Chamay, A., Tschantz, P. 1972. Mechanical influences in bone remodeling: experimental research on Wolff's Law. Journal of Biomedchanics 5, 173-180.

Churchill, S.E., Holliday, T.W., Carlson, K.J., Jashashvili, T., Macias, M.E., Mathews, S., Sparling, T.L., Schmid, P., Ruiter, D.J.D., Berger, L.R., 2013. The upper limb of Australopithecus sediba. Science 340, 1233477-1-6.

Clarke, R. J., 1998. First ever discovery of a well-preserved skull and associated skeleton of Australopithecus. South African Journal of Science 94, 460-463. 


\section{Heile et al.}

Clarke, R. J., 1999. Discovery of complete arm and hand of the 3.3 million-year-old Australopithecus skeleton from Sterkfontein. South African Journal of Science 95, 477-480.

Clarke, R. J., 2002. Newly revealed information on the Sterkfontein Member 2 Australopithecus skeleton. South African Journal of Science 98, 523-526.

Clarke, R. J., 2007. Taphonomy of Sterkfontein Australopithecus skeletons. In: Pickering, T.R., Schick, K., Schick, Toth, N. (Eds.), Breathing Life into Fossils: Taphonomic Studies in Honor of C.K. (Bob) Brain. Bloomington (IN): Stone Age Institute Press, pp. 195-201.

Clarke, R. J., 2008. A new look at Australopithecus and latest information on Sterkfontein's Australopithecus skeleton. South African Journal of Science 104, 443-449.

Clarke, R.J., 2012. The history of research in human evolution in Africa and what lessons have been learned. In: Sanz, N. (Ed.), Human Origins Sites and the World Heritage Convention in Africa. World Heritage Papers 33. UNESCO, New York, pp. 44-67.

Clarke, R.J., 2018. Excavation, reconstruction and taphonomy of the StW 573 Australopithecus skeleton from Sterkfontein Caves, South Africa. Journal of Human Evolution, in submission.

Clarke, R., Tobias, P., 1995. Sterkfontein member 2 foot bones of the oldest South African hominid. Science $269,521-524$.

Clarke, R., Kuman, K., Pickering, T.R., 2018. The skull of StW 573, a 3.67 My old Australopithecus skeleton from Sterkfontein Caves, South Africa. Journal of Human Evolution, in submission. 


\section{Heile et al.}

Cook, D.C., Buikstra, J.E., Derousseau, C.J., Johanson, D.C., 1983. Vertebral pathology in the Afar australopithecines. American Journal of Physical Anthropology 60, 83-101.

Crompton, R., McClymont, J., Thorpe, S., Sellers, W., Heaton, J., Pickering, T.R., Pataky, T., Stratford, D., Carlson, K., Jashashvili, T., Beaudet, A., Elton, S., Bruxelles, L., Goh, C., Kuman, K., Clarke, R. 2018. Ecomorphology of a female Australopithecus prometheus, StW 573, 3.67 Ma, from Sterkfontein Caves, South Africa: a review of the postcranial fossil evidence.

Crowe, J., Swischuk, L., 1977. Acute bowing fractures of the forearm in children: a frequently missed injury. American Journal of Roentgenology. 128, 981-984.

D’Anastasio, R., Zipfel, B., Moggi-Cecchi, J., Stanyon, R., Capasso, L., 2009. Possible brucellosis in an early hominin skeleton from Sterkfontein, South Africa. PLoS ONE 4, e6439.

Dhall, U., Signh, I., 1977. Anatomical evidence of one-sided forelimb dominance in the rhesus monkey. Anatomischer Anzeiger 141, 420-425.

Domínguez-Rodrigo, M., Pickering, T.R., Diez-Martín, F., Mabulla, A., Musiba, C., Trancho, G., Baquedano, E., Bunn, H., Barboni, D., Santonja, M., Uribelarrea, D., Ashley, G.M., Martínez-Ávila, M.D.S., Barba, R., Gidna, A., Yravedra, J., Arriaza, C., 2012. Earliest porotic hyperostosis on a 1.5million-year-old hominin, Olduvai Gorge, Tanzania. PLoS ONE 7, e46414. 


\section{Heile et al.}

Domínguez-Rodrigo, M., Pickering, T.R., Baquedano, E., Mabulla, A., Mark, D.F., Musiba, C., Bunn, H., Uribelarrea, D., Smith, V., Diez-Martin, F., Pérez-González, A., Sánchez, P., Santonja, M., Barboni, D., Gidna, A., Ashley, G., Yravedra, J., Heaton, J.L., Arriaza, M.C., 2013. First partial skeleton of a 1.34million-year-old Paranthropus boisei from Bed II, Olduvai Gorge, Tanzania. PLoS ONE 8, e80347.

Drapeau, M., 2004. Functional anatomy of the olecranon process in hominoids and Plio-Pleistocene hominins. American Journal of Physical Anthropology 124, 297-314.

Drapeau, M., 2008. Articular morphology of the proximal ulna in extant and fossil hominoids and hominins. Journal of Human Evolution 55, 86-102.

Drapeau, M., Ward, C., Kimbel, W., Johanson, D., Rak, Y., 2005. Associated cranial and forelimb remains attributed to Australopithecus afarensis from Hadar, Ethiopia. Journal of Human Evolution $48,593-642$.

Dugard, J., 1995. Palaeontologist Ron Clarke and the discovery of "Little Foot": a contemporary history. South African Journal of Science 91, 563-566.

Falk, D., Pyne, L., Helmkamp, R., DeRousseau, C. 1988. Directional asymmetry in the forelimb of Macaca mulatta. American Journal of Physical Anthropology 77, 1-6.

Galtés, I., Jordana, X., Malgosa, A., Manyosa, J., 2009. Technical note: forearm pronation efficiency analysis in skeletal remains. American Journal of Physical Anthropology 140, 589-594. 


\section{Heile et al.}

Granger, D.E., Gibbon, R.J., Kuman, K., Clarke, R.J., Bruxelles, L., Caffee, M.W., 2015. New cosmogenic burial ages for Sterkfontein Member 2 Australopithecus and Member 5 Oldowan. Nature 522, 8588.

Greene, W. 1982. Traumatic bowing of the forearm in an adult. Clinical Orthopaedics and Related Research 168, 31-34.

Guatelli-Steinberg, D., 2003. Macroscopic and microscopic analyses of linear enamel hypoplasia in Plio-Pleistocene South African hominins with respect to aspects of enamel development and morphology. American Journal of Physical Anthropology 120, 309-22.

Heaton, J., Pickering, T.R., Clarke, R. 2018. The long limb bones of the StW 573 Australopithecus skeleton from Sterkfontein Member 2: descriptions and the evolutionary implications of their proportions and indices. Journal of Human Evolution, in submission.

Heinrich, R.E., Rose, M.D., Leakey, R.E., Walker, A.C., 1993. Hominid radius from the middle Pliocene of Lake Turkana, Kenya. American Journal of Physical Anthropology 92, 139-148.

Howell, F.C., Wood, B., 1987. Early hominid ulna from the Omo Basin, Ethiopia. Nature 249, 174176.

Hunt, K., 1991. Mechanical implications of chimpanzee positional behavior. Am J Phys Anthropol 86, $521-536$. 


\section{Heile et al.}

Johanson, D.C., Lovejoy, C.O., Kimbel, W.H., White, T.D., Ward, S.C., Bush, M.E., Latimer, B.M.,Coppens, Y., 1982. Morphology of the Pliocene partial hominid skeleton (A.L. 288-1) from the Hadar Formation, Ethiopia. American Journal of Physical Anthropology 57, 403-451.

Kappelman, J., Ketcham, R., Pearce, S., Todd, L., Akins, W., Colbert, M., Feseha, M., Maisano, J., Witzel, A., 2016. Perimortem fractures in Lucy suggest mortality from fall out of tall tree. Nature 537, 503507.

Knussmann, V.R., 1967. Humerus, Ulna, und Radius der Simiae. S. Karger, Basel.

Komara, J., Kottamasu, L., Kottamusu, S., 1986. Acute plastic bowing fractures in children. Annals of Emergency Medicine 15, 585-588.

L'Abbe, E., Symes, S., Pokines, J., Cabo, L., Stull, K., Kuo, S., Raymond, D., Berger, L., 2015. Evidence of fatal skeletal injuries on Malapa Hominins 1 and 2. Nature Scientific Reports 5, 15120.

Lanyon, L., 1980. The influence of function on the development of bone curvature. Journal of Zoology 192, 457-466.

Latimer, B., Ohman, J., 2001. Axial dysplasia in Homo erectus. Journal of Human Evolution 40, A12.

Lefaivre, K., Slobogean, G., O’Brien, P., 2007. Plastic deformation of the forearm in an adult: treatment with multiple osteotomies. Clinical Orthopaedics and Related Research 462, 234-237. 


\section{Heile et al.}

Lovejoy, C.O., Johanson, D.C., Coppens, Y., 1982. Hominid upper limb bones recovered from the Hadar formation: 1974-1977 collections. American Journal of Physical Anthropology 57, 637-649.

Lovejoy, C.O., Latimer, B.M., Spurlock, L., Haile-Selassie, Y., 2016. The pelvic girdle and limb bones of KSD-VP-1/1. In: Haile-Selassie, Y., Su, D.F. (Eds.), The Postcranial Anatomy of Australopithecus afarensis. Springer, pp. 155-178.

McGrew, W., Marchant, L., 1997. On the other hand: current issues in the meta-analysis of the behavioral laterality of hand function in nonhuman primates. Yearbook of Physical Anthropology 40, 201-232.

Miller, R.A., 1933. Evolution of the pectoral girdle and fore limb in the primates. American Journal of Physical Anthropology 17, 1-56.

Musters, L., Colaris, J., 2017. Systematic review on the functional outcome after treatment of a traumatic bowing fracture of the lower arm in children. Journal of Trauma Treatment 6, 384.

Naga, A.H., Broadrick, G.L., 1977. Traumatic bowing of the radius and ulna in children. North Carolina Medical Journal 38, 452-456.

Njau, J., Blumenschine, R., 2006. A diagnosis of crocodile feeding traces on larger mammal bone, with fossil examples from the Plio-Pleistocene Olduvai Basin, Tanzania. Journal of Human Evolution 50, 142-162. 


\section{Heile et al.}

Pickering, T. R., Clarke, R. J., Heaton, J. L., 2004. The context of StW 573, an early hominid skull and skeleton from Sterkfontein Member 2: taphonomy and paleoenvironment. Journal of Human Evolution 46, 277-295.

Pickering, T.R., Heaton, J., Clarke, R., Stratford, D. 2018. Hominin vertebrae and upper limb bone fossils from Sterkfontein Caves, South Africa (1998 - 2003 excavations). American Journal of Physical Anthropology, in press.

Rein, T.R., Harrison, T., Carlson, K.J., Harvati, K., 2017. Adaptation to suspensory locomotion in Australopithecus sediba. Journal of Human Evolution 104, 1-12.

Richmond, B.G., 2007. Biomechanics of phalangeal curvature. Journal of Human Evolution 53, 678690.

Ripamonti, U., Kirkbride, A., Yates, S., Thackeray, J., 1997. Further evidence of periodontal bone pathology in a juvenile specimen of Australopithecus africanus from Sterkfontein, South Africa. South African Journal of Science 93, 177-78.

Robinson, J. T., 1956. The Dentition of the Australopithecinae. Transvaal Museum Memoirs, no. 9.

Rothschild, B.M., Hershkovitz, I., Rothschild, C., 1995. Origin of yaws in the Pleistocene. Nature 378, $343-344$.

Sanders, W., Heckman, J., 1984. Traumatic plastic deformation of the radius and ulna: a closed method of correction of deformity. Clinical Orthopaedics and Related Research 188, 58-67. 


\section{Heile et al.}

Sarringhaus, L., Stock, J., Marchant, L., McGrew, W., 2005. Bilateral asymmetry in the limb bones of the chimpanzee (Pan troglodytes). American Journal of Physical Anthropology 128, 840-845.

Schultz, A., 1937. Proportions, variability and asymmetries of the long bones of the limbs and the clavicles in man and apes. Human Biology 9, 281-328.

Sclamberg, J., Sonin, A., Sclamberg, E.,D’Sonza, N., 1998. Acute plastic bowing of the forearm in an adult.

Sen, R.K., Jain, J.K., Nagi, O.N., 2004. Traumatic bowing of the forearm bones in roller machine injuries. Injury 35, 1202-1206.

Simonian, P., Hanel, D., 1996. Traumatic plastic deformation of an adult forearm: case report and literature review. Journal of Orthopaedic Trauma 10, 213-215.

Stratford, D.J., Granger, D.E., Bruxelles, L., Clarke, R.J., Kuman, K., Gibbon, R.J., 2017. Comments on “The age of fossil StW573 ('Little Foot'): an alternative interpretation of ${ }^{26} \mathrm{Al} /{ }^{10} \mathrm{Be}$ burial data"' South African Journal of Science 113, 1-3.

Susman, R.L., 1979. Comparative and functional morphology of hominoid fingers. American Journal of Physical Anthropology 50, 215-236.

Swartz, S.M., 1990. Curvature of the forelimb bones of anthropoid primates: overall allometric patterns and specializations in suspensory species. American Journal of Physical Anthropology 83, 477-498. 


\section{Heile et al.}

Tada, K., Ikeda, K., Tsubouchi, H., Tomita, K., 2008. Acute plastic bowing of the forearm in adults: a report of two cases. Journal of Orthopaedic Surgery 16, 241-242.

Tianhao, W., Yueju, L., Yingze, Z., Xirui, W., 2014. Plastic deformation of the forearm in adults: an analysis of 30 cases. Journal of Orthopaedic Surgery and Research 9, 117-120.

Tobias, P.V., 1991. Olduvai Gorge Volume 4: The Skulls, Endocasts, and Teeth of Homo habilis. Cambridge University Press, Cambridge.

Toussaint, M., Macho, G.A., Tobias, P.V., Partridge, T.C., Hughes, A., 2003. The third partial skeleton of a late Pliocene hominin (StW 431) from Sterkfontein, South Africa. South African Journal of Science 99, 215-223

Vorlat, P., De Boeck, H., 2003. Bowing fractures of the forearm in children. Clinical Orthopaedics and Related Research 413, 233-237.

Walker, A., 1993. Taphonomy. In: Walker, A., Leakey, R. (Eds.), The Nariokotome Homo erectus Skeleton. Cambridge: Harvard University Press.

Walker, A., Zimmerman, M.R., Leakey, R.E.F., 1982. A possible case of hypervitaminosis A in Homo erectus. Nature 296, 248-250.

White, T.D., 1978. Early hominid enamel hypoplasia. American Journal of Physical Anthropology 49, 79-83. 
bioRxiv preprint doi: https://doi.org/10.1101/486076; this version posted December 5, 2018. The copyright holder for this preprint (which was not certified by peer review) is the author/funder, who has granted bioRxiv a license to display the preprint in perpetuity. It is made available under aCC-BY-NC-ND 4.0 International license.

\section{Heile et al.}

White, T.D., 2002. Earliest hominids. In: Hartwig, W. (Ed.), The Primate Fossil Record.

Cambridge University Press, Cambridge, pp. 407-417.

White, T.D., Lovejoy, C.O., Asfaw, B., Carlson, J.P., Suwa, G., 2015. Neither chimpanzee nor human, Ardipithecus reveals the surprising ancestry of both. Proceedings of the National Academy of Sciences (USA) 16, 4877-4884. 
Heile et al.

Table 1. Ulna measurement abbreviations and definitions used in this study

\begin{tabular}{ll}
\hline Curvature & $\begin{array}{l}\text { "Ulnar diaphyseal curvature measured as the maximum distance from the } \\
\text { posterior-most margin of the bone and a line drawn between two inflexion points } \\
\text { on the posterior margin of the diaphysis, one at the level of the radial notch and } \\
\text { the other at the level of minimal distal circumference" (curvature subtense) } \\
\text { (Drapeau et al. 2005: 609; see also Aiello et al. 1999) }\end{array}$ \\
Length & $\begin{array}{l}\text { Physiological length from proximodistal center of the trochlear notch to the } \\
\text { distalmost point on the head (Knussmann 1967) }\end{array}$ \\
Mid AP & Anteroposterior diameter at midshaft
\end{tabular}

Table 2. Measurements of complete and near-complete Australopithecus and Paranthropus ulnaea,b

\begin{tabular}{llrrr}
\hline Genus & Specimen & Lengthc & Mid APd & Curvature $^{\mathrm{e}}$ \\
\hline Australopithecus & AL 288-1 & $181 / 206$ & 12.3 & $2.5 / 4.1$ \\
& AL 438-1 & 252 & 17.6 & 7.5 \\
& MH2 & 233 & {$[11.7]$} & {$[4]$} \\
& StW 573 & 244 & 14.2 & {$[12]$} \\
Paranthropus & L40-19 & 295 & 14.8 & 12.5 \\
& OH 36 & $247 / 277$ & 17.3 & $13.9 / 15.7$ \\
\hline
\end{tabular}

aMeasurements described in Table 1. All measurements in millimeters. Values in brackets represent estimates

bFor taxonomic assignments, see Johanson et al. (1982), Howell et al. (1987), Aiello et

al. (1999), Clarke (1998), Drapeau et al. (2005), and Berger et al. (2010)

cData for AL 288-1, AL 438-1, L40-19, and OH 36 from Drapeau et al. (2005); MH2

from Churchill et al. (2013); StW 573 from Heaton et al. (in submission)

dData for AL 288-1, AL 438-1, L40-19, and OH 36 from Drapeau et al. (2005); MH2

estimated from image software using scaled photo from Rein et al. (2017); StW 573

from Heaton et al. (in submission)

eData for AL 288-1, AL 438-1, L40-19, OH 36 from Drapeau et al. (2005); MH2

estimated from image software using scaled photo from Rein et al. (2017); StW 573

from Heaton et al. (in submission) 


\section{Heile et al.}

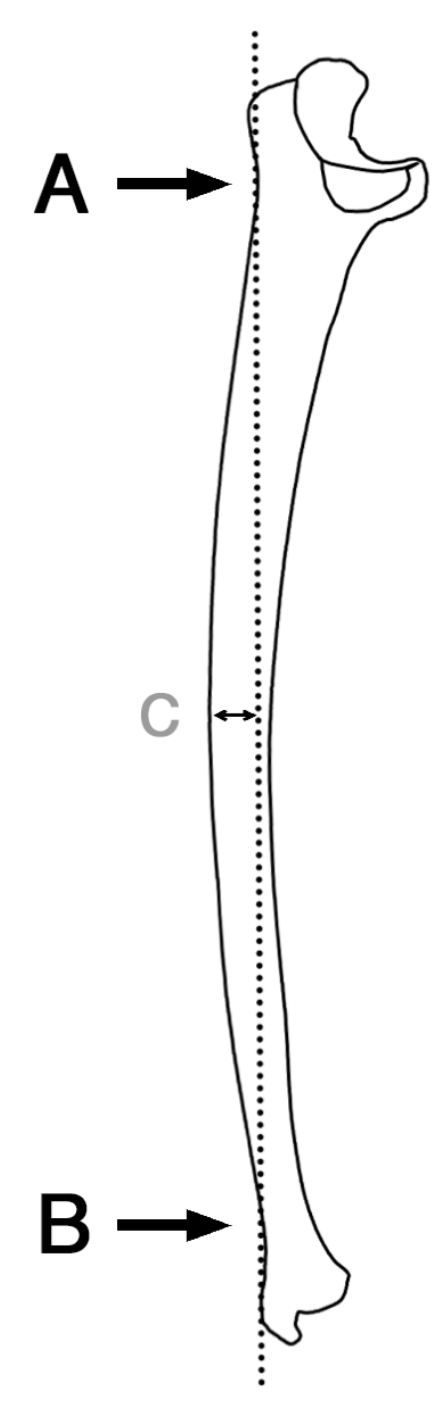

Figure 1. Sketch of a Pan troglodytes right ulna shown in lateral view to illustrate calculation of curvature subtense, where A indicates the inflection point on the posterior margin of the ulna at the level of the radial notch, B indicates a second inflection point on the posterior margin of the ulna at the minimal distal circumference, and $\mathrm{C}$ indicates the maximum distance from the posterior-most margin of the ulna to the line drawn between A and B (Aiello et al. 1999; Drapeau et al. 2005). Figure modified from Drapeau et al. (2005: 618, Fig. 16). 
bioRxiv preprint doi: https://doi.org/10.1101/486076; this version posted December 5, 2018. The copyright holder for this preprint (which was not certified by peer review) is the author/funder, who has granted bioRxiv a license to display the preprint in perpetuity. It is made available under aCC-BY-NC-ND 4.0 International license.

\section{Heile et al.}

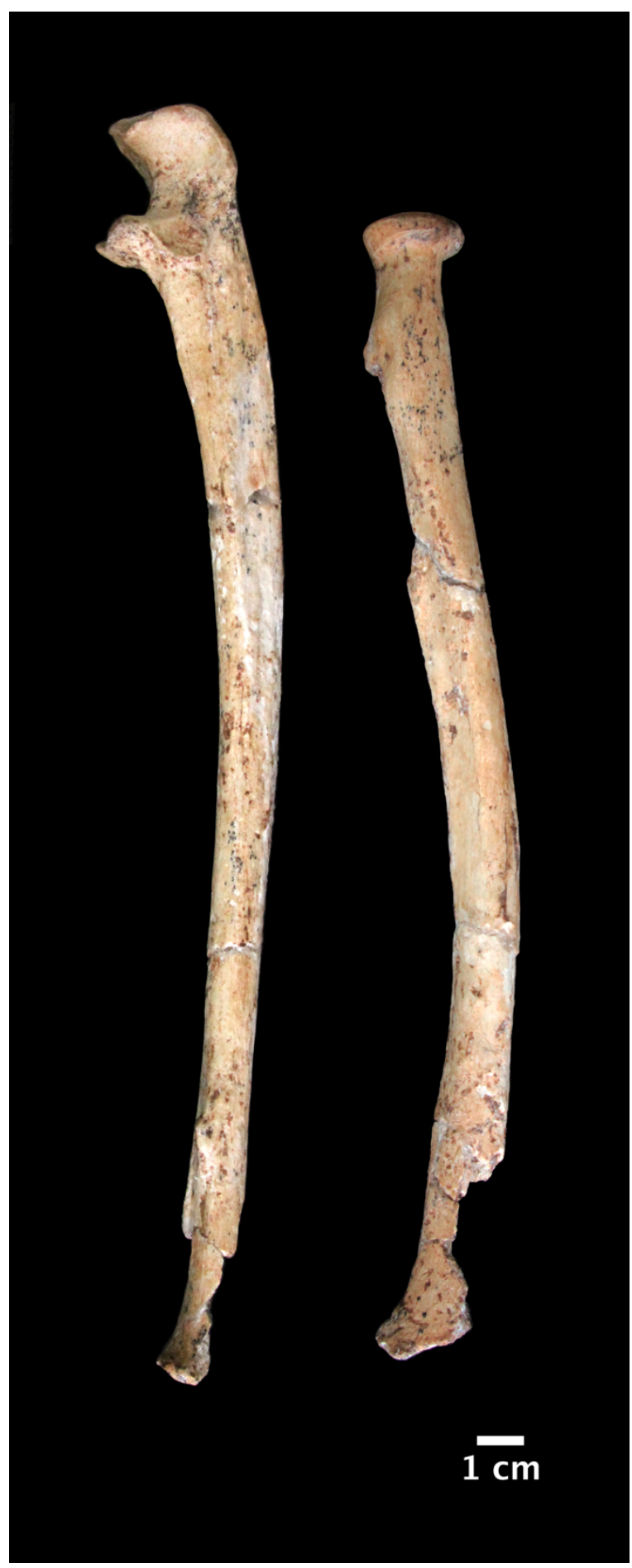

Figure 2. The curved left forearms bones of the StW 573 Australopithecus skeleton shown with superior toward the top of the image. The ulna (left) is near-lateral view and radius (right) is in anterior view. 